\title{
SHEAR STRENGTH OF SOILS FROM THE DOBKOVIČKY LANDSLIDE IN THE CENTRAL BOHEMIAN UPLANDS DETERMINATED BY LABORATORY TESTS
}

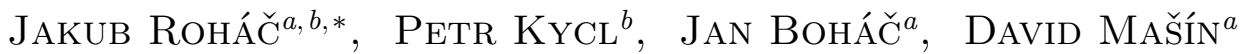 \\ ${ }^{a}$ Charles University, Faculty of Science, Albertov 6, Prague \\ ${ }^{b}$ Czech Geological Survey, Klárov 3, Prague \\ * corresponding author: jakub.rohac@geology.cz
}

\begin{abstract}
The aim of this paper is to evaluate soil shear strength from the Dobkovicky landslide. The landslide was activated on June 6, 2013 after heavy rains and the D8 motorway, which was under construction at the time, was damaged. The laboratory tests were carried out on two types of soils, clay and tuff, both from the surface of the rupture. Critical and residual friction angles were evaluated on both types of soils.
\end{abstract}

KEYwORDS: Laboratory tests, the Dobkovičky landslide, shear strength.

\section{INTRODUCTION}

The plans for a highway connecting Prague with Dresden have been debated since the 1930s. Construction of the first $4.2 \mathrm{~km}$ of the $92 \mathrm{~km}$ long D 8 motorway began with section 0806 Rehlovice - Ústí nad Labem nearly 50 years later in 1984 . The construction of the last remaining $16.2 \mathrm{~km}$ in section 0805 Lovosice Rehlovice was launched in 2007. This section crossed the Central Bohemian Uplands, which represent the most geologically complex and problematic part of the motorway, in particular due to the presence of a large area of dormant and abandoned landslides known as "Prackovice landslides" intersected by the motorway. On Friday, June 7, 2013 the works were interrupted and the motorway under construction was damaged when heavy rains triggered a landslide near the village of Dobkovičky ( $\mathrm{km}$ 56.3-56.5). The damage was not restricted only to the motorway but also affected the single-track railway connecting Lovosice with Teplice between the stations Dobkovičky and Radejčín. The railway track was completely destroyed in the length of $200 \mathrm{~m}$, including a $6 \mathrm{~m}$ high embankment.

\section{DoBKOVIČKY LANDSLIDE}

Dobkovičky landslide (Fig. 1) was activated in the well-mapped landslide area of Prackovice, which is characterized by landslides in its geological history. The whole area from the river Labe up to the railway embankment is covered by morphologically visible landslides. On June 3, 2013, the first cracks were observed in the area of Dobkovičky quarry after 4 days of heavy rains. The Dobkovičky landslide was activated in the evening of June 6, 2013.

\subsection{LANDSLIDE DESCRIPTION}

The planar surface of the rupture was detected at a depth of 4-6.5 m below ground level by an engineeringgeological survey provided by the company AZ Consult

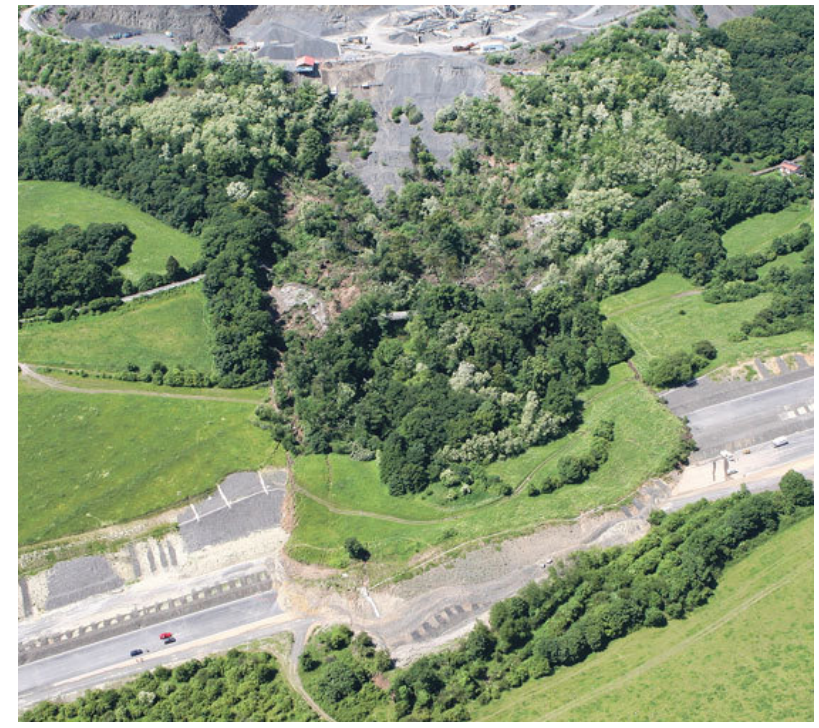

Figure 1. Picture of the landslide after collapse (summer 2013).

[1. The length was 470 meters and width was 200 meters. The maximum length of the movement in the center of the landslide was $49 \mathrm{~m}$ and the maximum speed of the movement was 1 meter per hour on June 8 [2].

\subsection{Geology And hydRogeology}

The surface of the rupture of Dobkovičky landslide consists of siltstone, altered basalt, tuff and anthropogenic material. The anthropogenic material is located in the center of the landslide in the form of a railway embankment and on the top of the landslide in the form of a dump of material from Dobkovičky quarry. Weathered chalky siltstone (clayey character, R6) represented the slip surface from the toe to the railway line as documented in the minor scarp and in the place of the railway embankment. Basalt (R4) was 


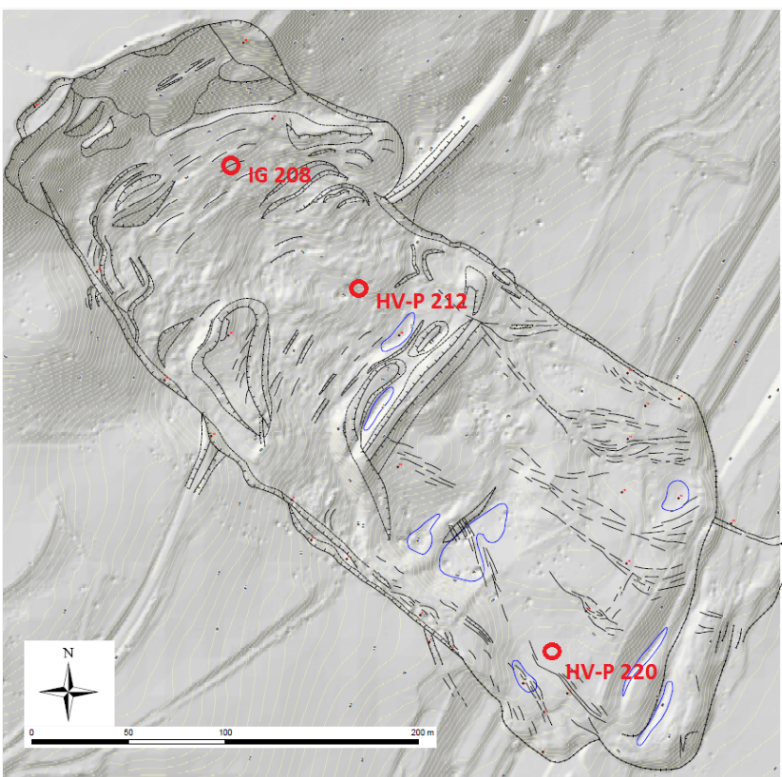

Figure 2. Map of the landslide with sampling points.

\begin{tabular}{|l|l|l|l|l|l|}
\hline Type & Sample & Depth $[\mathrm{m}]$ & $\mathrm{W}_{\mathrm{L}}$ & $\mathrm{W}_{\mathrm{P}}$ & $\mathrm{I}_{\mathrm{P}}$ \\
\hline \hline Kts & HV-P220 & $8.3 \mathrm{~m}$ & 59.3 & 24.8 & 34.5 \\
\hline Kts1 & HV-P212 & $2.3 \mathrm{~m}$ & 62.5 & 25.5 & 37 \\
\hline$T f$ & IG 208 & $6.5 \mathrm{~m}$ & 87.1 & 52.2 & 34.9 \\
\hline
\end{tabular}

TABLE 1. Index properties

documented above the railway embankment up to the main scarp. Neogene tuff had a sandy clay character with pieces of coal. It had an irregular representation in the surface of the rupture.

The main source of groundwater is quaternary debris. The stratum of fresh and weathered siltstone is considered as a hydrogeological insulator 3 . The general groundwater flow direction is from north-west to south-east. Hydrogeology of Dobkovičky quarry is characterized by fissured permeability, it can be assumed that most of the rainwater is drained through the fissures to the top of the impermeable siltstones and drained to the slope under the quarry.

\section{SAMPLE DESCRIPTION}

The laboratory tests were carried out on two types of soils, clay and tuff, both from the slip surface. Samples were taken during the engineering-geological research in 2014 and 2015. There are 3 main IG types of material: Kts1-cretaceous silt stone, olive-colored (borehole HV-P 212), Kts-cretaceous siltstone, bluegray colored (borehole HV-P 220), and Tf -tertiary tuff, yellow colored (borehole IG 208) [1]. Sampling points are labeled on Fig. 2. The grading curves of the three main IG types are shown in Fig. 3 . Index properties are described in Tab. 1, where $W_{L}$ is the liquid limit, $\mathrm{W}_{\mathrm{P}}$ is the plastic limit and $\mathrm{I}_{\mathrm{P}}$ is the plasticity index.

\section{SAMPLE PREPARATION AND TEST PROCEDURES}

All of the laboratory tests were carried out in the laboratory of soil mechanic at the Faculty of Science. Critical parameters were evaluated in a conventional triaxial apparatus and in a shearbox. Residual parameters were evaluated in a ring shear apparatus. All of the laboratory tests were carried out on reconstituted soils - the material was thoroughly mixed with distilled water until a homogeneous slurry was obtained. The final water content of the slurry was approximately 1.5 times higher than the liquid limit of the material. The material was then sieved through a $2 \mathrm{~mm}$ mesh sieve.

\subsection{TRIAXIAL TEST}

CIUP triaxial test (Consolidated Isotropic Undrained with Pore pressure measurement). The slurry was poured carefully into a consolidometer and consolidated to a vertical stress of approximately $80 \mathrm{kPa}$. The load was applied with increments of $10 \mathrm{kPa}$ every day to prevent squeezing up the sides of the piston. After two weeks, the sample was extruded and its ends were trimmed to the correct length of $78 \mathrm{~mm}$, the diameter was $38 \mathrm{~mm}$. The sample was measured and the mass of the sample was determined. Then the sample was placed into the triaxial cell on a base pedestal. Radial drains were used for all of the samples to reduce the duration of the tests. Top drainage was not used. The samples were isotropically consolidated and sheared in an undrained condition with pore pressure measurements.

\subsection{Shear BOX TEST}

Tests were carried out on reconstituted slurry, which was consolidated to a vertical stress of $60 \mathrm{kPa}, 100 \mathrm{kPa}$ and $150 \mathrm{kPa}$. The speed of shear was lower than $0.0013 \mathrm{~mm} / \mathrm{min}$ to ensure drained conditions.

\subsection{RING SHEAR TEST}

A Bromhead ring shear apparatus was used for evaluation of the residual shear strength. The test was carried out, similarly to the previous apparatus, on reconstituted soils. Slurry was consolidated to a vertical stress of $30 \mathrm{kPa}, 50 \mathrm{kPa}$ and $70 \mathrm{kPa}$. The speed of shear was lower than $0.023 \mathrm{~mm} / \mathrm{min}$.

\section{Results}

Table 2 shows the results, the types of tests and the used stresses. Eighteen laboratory test were carried out for evaluation of the shear strength of the soils from the Dobkovičky landslide. Nine of them were CIUP (Consolidated Isotropic Undrained with Pore pressure measurement) triaxial tests, three were shear box tests and six were ring shear tests. The results of the three selected tests are shown in Fig. 4. The shear parameters of the tuff are slightly higher than the clays. The residual parameters are approximately 


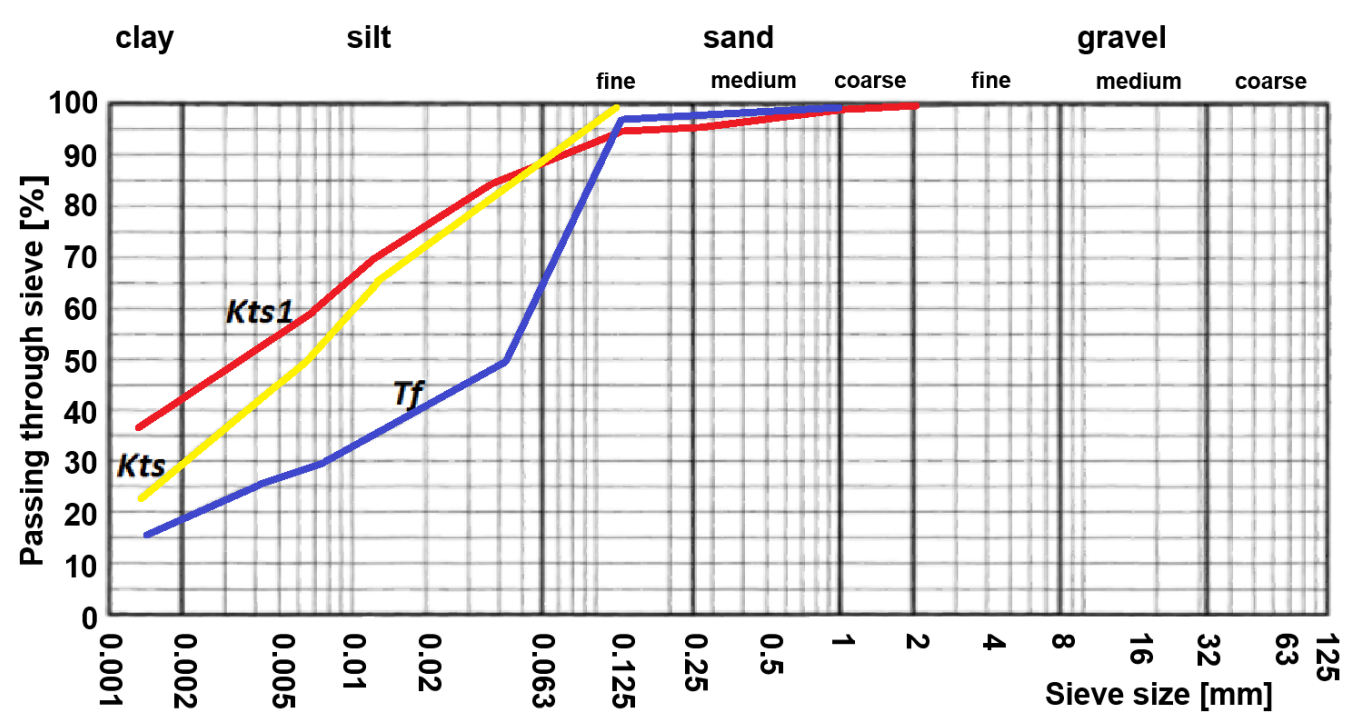

Figure 3. Grading curves of the three main IG types of soils, after [4]

\begin{tabular}{|c|c|c|c|}
\hline Sample & Type & Laboratory test & Shear strength \\
\hline \multirow[t]{3}{*}{ IG 208} & $T f$ & $\begin{array}{l}\text { Triaxial compression test CIUP, } \\
\text { effective stress } 60 \mathrm{kPa}, 120 \mathrm{kPa} \text { a } 200 \mathrm{kPa}\end{array}$ & $\varphi_{\mathrm{cr}}=29,5^{\circ}$ \\
\hline & & $\begin{array}{l}\text { Direct shear test, normal stress } 60 \mathrm{kPa}, 100 \\
\mathrm{kPa} \text { a } 150 \mathrm{kPa}\end{array}$ & $\varphi_{\mathrm{cr}}=31,2^{\circ}$ \\
\hline & & $\begin{array}{l}\text { Ring shear test, normal stress } 30 \mathrm{kPa}, 50 \mathrm{kPa} a \\
70 \mathrm{kPa}\end{array}$ & $\varphi_{\text {res }}=15,3^{\circ}$ \\
\hline HV-P 220 & Kts & $\begin{array}{l}\text { Triaxial compression test CIUP, } \\
\text { effective stress } 70 \mathrm{kPa}, 120 \mathrm{kPa} \text { a } 200 \mathrm{kPa}\end{array}$ & $\varphi_{c r}=25,7^{\circ}$ \\
\hline \multirow[t]{2}{*}{ HV-P 212} & Kts1 & $\begin{array}{l}\text { Triaxial compression test CIUP, } \\
\text { effective stress } 70 \mathrm{kPa}, 120 \mathrm{kPa} \text { a } 200 \mathrm{kPa}\end{array}$ & $\varphi_{c r}=25,1^{\circ}$ \\
\hline & & $\begin{array}{l}\text { Ring shear test, normal stress } 30 \mathrm{kPa}, 50 \mathrm{kPa} a \\
70 \mathrm{kPa}\end{array}$ & $\varphi_{\text {res }}=13,3^{\circ}$ \\
\hline
\end{tabular}

TABLE 2. Results of shear strength tests

$\frac{1}{2}$ of the critical parameters of the same sample, which confirms the known theory of soil mechanics 5 .

\section{Conclusions}

The presented laboratory tests confirm that shear strength depends on the movement of the slip surface. Residual shear strength reached a value of between 13 and $15^{\circ}$, which is approximately one half of the critical values [5]). It is planned to extend the number of laboratory tests within the study to create a detailed numerical model of the Dobkovičky landslide.

\section{REFERENCES}

[1] J. Suchý. D8 - odstranění sesuvu v km 56,300 - 56,500 + stabilizace oblasti kolem stavby D8 - 0805. Tech. rep., AZ Consult, 2014.

[2] P. Kycl. Situační zpráva o sesuvu Dobkovičky D8 km 56,300 ke dni 11. června 2013. Tech. rep., Česká geologická služba, 2013.

[3] J. Záruba. Inženýrskogeologický doprůzkum, stabilitní výpočty v km 56,160 - 56,660. Tech. rep., Arcadis geotechnika, 2011.
[4] Z. J. S. J. Plšková, M. Předběžná zpráva d8-0805

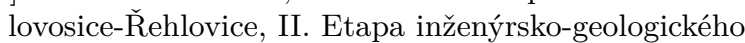
dopruzkumu v oblasti sesuvu Dobkovičky a v jeho předpolí v km 56.300-56.500. Tech. rep., 2016.

[5] J. Atkinson. The mechanics of soils and foundations. CRC Press, 2007. 

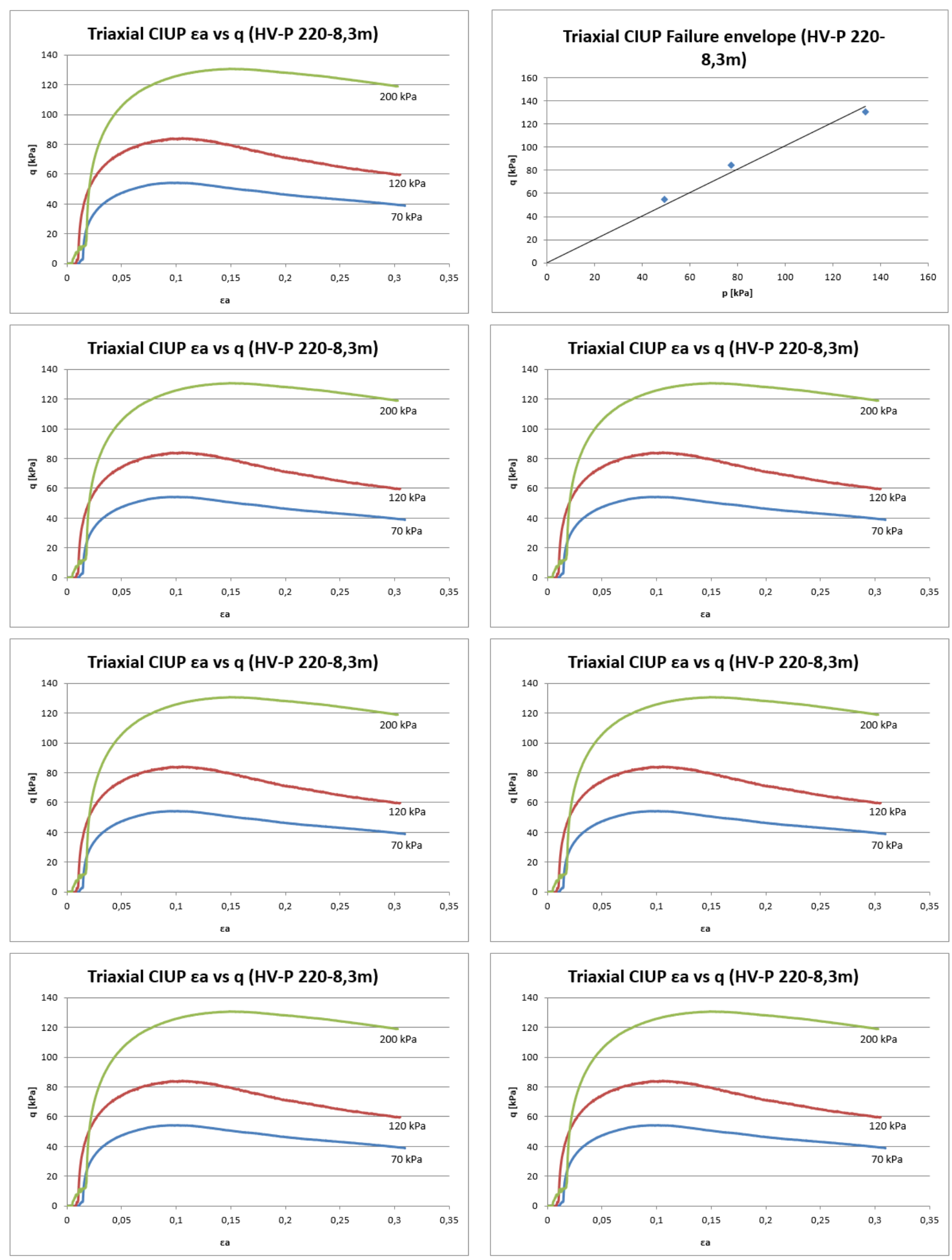

Figure 4. The results of performed tests 